\title{
Interactions of L-Aspartic Acid with Aqueous Solution of 1,2-Propanediol at Different Temperatures: A Volumetric, Compressibility and Viscometric Approach
}

\author{
Ruby Rani, ${ }^{1}$ Ashwani Kumar, ${ }^{1}$ Tanu Sharma, ${ }^{1}$ Balwinder Saini ${ }^{2}$ \\ and Rajinder Kumar Bamezai ${ }^{1, *}$ \\ ${ }^{1}$ Department of Chemistry, University of Jammu, Jammu - 180 006, India. \\ ${ }^{2}$ School of Physical Sciences, Lovely Professional University, Phagwara (Punjab) - 144 402, India. \\ * Corresponding author: E-mail: rkb10@ rediffmail.com
}

Received: 12-01-2016

\begin{abstract}
The volumetric, acoustic and viscometric methods are used for investigating the interactions of L-aspartic acid (Asp) in aqueous solution of 1,2-propanediol (PD) over a temperature of $(298.15,303.15$ and 308.15$) \mathrm{K}$ at atmospheric pressure. Using the experimental results, the apparent molar volume, $\mathrm{V}_{\phi}$, limiting apparent molar volume, $\mathrm{V}_{\phi}^{0}$, the slope, $\mathrm{S}_{\mathrm{v}}$, and partial molar volume of transfer, $\mathrm{V}_{\phi}^{0}$,tr have been calculated from density data. The apparent molar isentropic compressibility, $\mathrm{K}_{\phi, s}$, limiting apparent molar isentropic compressibility, $\mathrm{K}_{\phi, s}^{0}$, its slope, $\mathrm{S}_{\mathrm{k}}$, and partial molar compressibility of transfer, $\mathrm{K}_{\phi, s, \mathrm{tr}}^{0}$, have been calculated from speed of sound data. These values are also used for calculating the number of water molecules hydrated, $n_{H}$, to the Asp. The viscosity data has also been used to determine relative viscosity $\eta_{\mathrm{r}}$, viscosity B-coefficients, temperature derivative of B-coefficients, $\mathrm{dB} / \mathrm{dT}$ and viscosity B-coefficients of transfer, $\mathrm{B}_{\mathrm{tr}}$. The calculated parameters have been discussed in terms of various solute-solute and solute-solvent interactions prevailing in these solutions. Further, a detailed insight into the physicochemical interactions between Asp and aqueous PD, e.g., ion-hydrophilic and hydrophilic-hydrophilic interactions along with the structure-making tendency have been retrieved through the perusal of these calculated parameters.
\end{abstract}

Keywords: L-aspartic acid, Apparent molar volume, 1, 2-Propanediol, Transport properties

\section{Introduction}

The physicochemical and thermodynamic properties of amino acids are of utmost interest, as these biomolecules are the building blocks of all living organisms which provide valuable information leading to a better understanding of proteins. Since proteins are large complex molecules, their direct study of interactions become difficult. Therefore, the feasible approach is to investigate interactions of the model compounds of proteins, e.g., amino acids, in aqueous and mixed-aqueous solutions. ${ }^{1-6}$ The choice of water for preparing mixed solvent stems from its important and unique role in determining the structure and stability of protein. Its presence also gives rise to hydrophobic forces, which are of prime importance in stabilizing native globular structure of protein.${ }^{7,8}$ Binary solvents, representing a concentrated mixture of a co-sol- vent and water as the principal solvent, are of special interest from both the biological and the physico-chemical view points. ${ }^{9-11}$ The added co-solvent may exert a stabilizing or destabilizing influence or neutral effect ${ }^{12}$ on the native conformation of a protein.

It is known that polyhydric alcohols increase the thermal stability of proteins or reduce the extent of their denaturation by other substances. ${ }^{13,14}$ The alkane diols have wide range of applications in pharmacology and cosmetic industry, however, they are not components of living organisms, but they act as a vehicle for pharmaceuticals or cosmetics when introduced into living organisms. ${ }^{15}$ Thus, the properties of amino acids in aqueouspolyols solutions are essential in understanding the chemistry of biological systems. ${ }^{16-18}$

The literature survey reveals physical and thermodynamic studies on Asp (abbreviated as Asp) and inor- 
ganic salts as a function of temperature ${ }^{19,20}$ but no report seems to be available on thermodynamic studies of Asp and organic solvents. However, the effect of dielectric constant on protonation equilibria of Asp in one of the alkane diol-water mixtures has been reported recently by Rani et al. ${ }^{21}$. In order to gather information about thermodynamic and transport properties of Asp in aqueous and aqueous-1, 2-propanediol (the latter being abbreviated as PD) solvent, we are using volumetric, compressibility and viscosity approaches at different temperatures.

\section{Experimental}

Asp and PD with mass fraction purity $>99 \%$ obtained from Sigma Aldrich were used as such without further purification. Freshly prepared triply distilled with specific conductance less than $1 \times 10^{-6} \mathrm{~S} \mathrm{~cm}^{-1}$ was used for the preparation of solutions in which $0.5 \mathrm{M}$ hydrochloric acid was added to increase the solubility. ${ }^{21}$ The aqueous solution of PD was used as solvent to prepare solutions of Asp of different molal concentrations. All the solutions were prepared with care and stored in special airtight bottles to avoid the exposure of solutions to air and evaporation. The solutions were prepared by weighing on an electronic single pan five digit Mettler Balance (Model AE-240) with an accuracy of $\pm 0.01 \mathrm{mg}$. The densities of the solutions were automatically measured, using an Anton Paar DMA 5000M densimeter. A density check or an air/water adjustment was performed at $20{ }^{\circ} \mathrm{C}$ with triply distilled, degassed water, and with dry air at atmospheric pressure. As the density is extremely sensitive to temperature, it was controlled to $\pm 1 \times 10^{-3} \mathrm{~K}$ by built-in Peltier device. The sensitivity of the instrument corresponds to a precision in density measurements of $1 \times 10^{-3} \mathrm{~kg} \mathrm{~m}^{-3}$. The uncertainty of the density estimates was found to be within $\pm 5 \times 10^{-2} \mathrm{~kg} \mathrm{~m}^{-3}$. The speeds of sound in the solutions were measured using a single-crystal variable-path multi-frequency ultrasonic interferometer (M-82, Mittal Enterprises) having stainless steel sample cell (with digital micrometer) operating at fixed frequency of $4 \mathrm{MHz}$. The uncertainty in speeds of sound measurements was found to be within $\pm 0.5 \mathrm{~m} \mathrm{~s}^{-1}$. The temperature of the sample solutions was maintained to an accuracy of $\pm 0.01 \mathrm{~K}$ in an electronically controlled thermostatic water bath (Model: TIC-4000N, Thermotech, India). The viscosities of the solutions were measured by using Ubbelohde viscometer. The viscometer containing the test liquid was allowed to stand for about 30 minutes in a thermostatic water bath so that the thermal fluctuations in viscometer were minimized. The time of flow was recorded with a digital stopwatch with an accuracy of $\pm 0.01 \mathrm{~s}$. The accuracy of viscosity measurements was found to be $\pm 1 \times 10^{-6} \mathrm{~Pa} \mathrm{~s}$.

\section{Results and Discussion}

\section{1. Apparent Molar Volume}

The experimental values of densities of Asp in aqueous and $5 \%, 10 \%, 15 \%$ and $20 \%$ aqueous solutions of PD, measured at $298.15,303.15$ and $308.15 \mathrm{~K}$, were used to calculate apparent molar volume $\left(\mathrm{V}_{\phi}\right)$ of the solutions using Eq. (1).

$$
\mathrm{V}_{\phi}=(\mathrm{M} / \rho)-\left[\left(\rho-\rho_{\mathrm{o}}\right) 1000 / \mathrm{m} \rho \rho_{\mathrm{o}}\right]
$$

where $\mathrm{m}$ is the molality $\left(\mathrm{mol} \mathrm{kg}{ }^{-1}\right.$ ) of the solution, $\mathrm{M}$ is the molar mass of the solute $\left(\mathrm{kg} \mathrm{mol}^{-1}\right)$, and $\rho_{\mathrm{o}}$ and $\rho$ are the densities $\left(\mathrm{kg} \mathrm{m}^{-3}\right)$ of the solvent and solution, respectively.

The values of densities and apparent molar volume at various temperatures are reported in Table 1 , while the curve for latter is presented in Figure 1. The results reveal that the apparent molar volume increases with increase in PD concentration as well as temperature. This may be attributed to the increase in solvation (release of some solvent molecules from loose solvation layers of the solute in solution) of Asp at higher temperature as well as at higher concentration of PD due to strong attractive interactions. ${ }^{22}$ The high value of apparent molar volume for Asp in different concentrations of solvent (5\% PD to 20\% PD) as compared to their values in aqueous solution suggests that ionhydrophilic and hydrophilic-hydrophilic interactions dominate the ion-hydrophobic and hydrophobic-hydrophobic interactions.

\section{1. 1. Limiting Apparent Molar Volume}

The limiting apparent molar volume $\left(\mathrm{V}_{\phi}^{\mathrm{o}}\right)$, also known as partial molar volume, has been obtained by employing the least square fitting of apparent molar volume values to the linear Eq. (2).

$$
\mathrm{V}_{\phi}=\mathrm{V}_{\phi}^{0}+\mathrm{S}_{\mathrm{v}} \mathrm{m}
$$

where $S_{v}$, the experimental slope, indicates the nature of the solute-solute interactions, while $\mathrm{V}_{\phi}^{0}$ shows the presence of solute-solvent interactions. The values of $\mathrm{S}_{\mathrm{v}}, \mathrm{V}_{\phi}^{0}$ along with their standard errors, reported in Table 2, show less positive behavior for $S_{v}$, thus, suggesting that solute-solute interactions are weak. On the contrary, the values of $\mathrm{V}_{\phi}^{0}$ are positive and show an increasing behaviour with increase in concentration of PD as well as increase in temperature, thus, indicates dominance of solutesolvent interaction in the system. Our values of $\mathrm{V}_{\phi}^{0}$ of Asp in aqueous solution at $298.15 \mathrm{~K}$ and $308.15 \mathrm{~K}$ resemble to the values reported by Banipal et al. ${ }^{19}$ which is shown in parenthesis in Table 2, whereas the data at $303.15 \mathrm{~K}$ could not be found in the literature. The value at $298.15 \mathrm{~K}$ is also in close agreement with the values obtained from the work of Millero et al. ${ }^{23}$ and Mishra and Ahluwalia. ${ }^{24}$ 

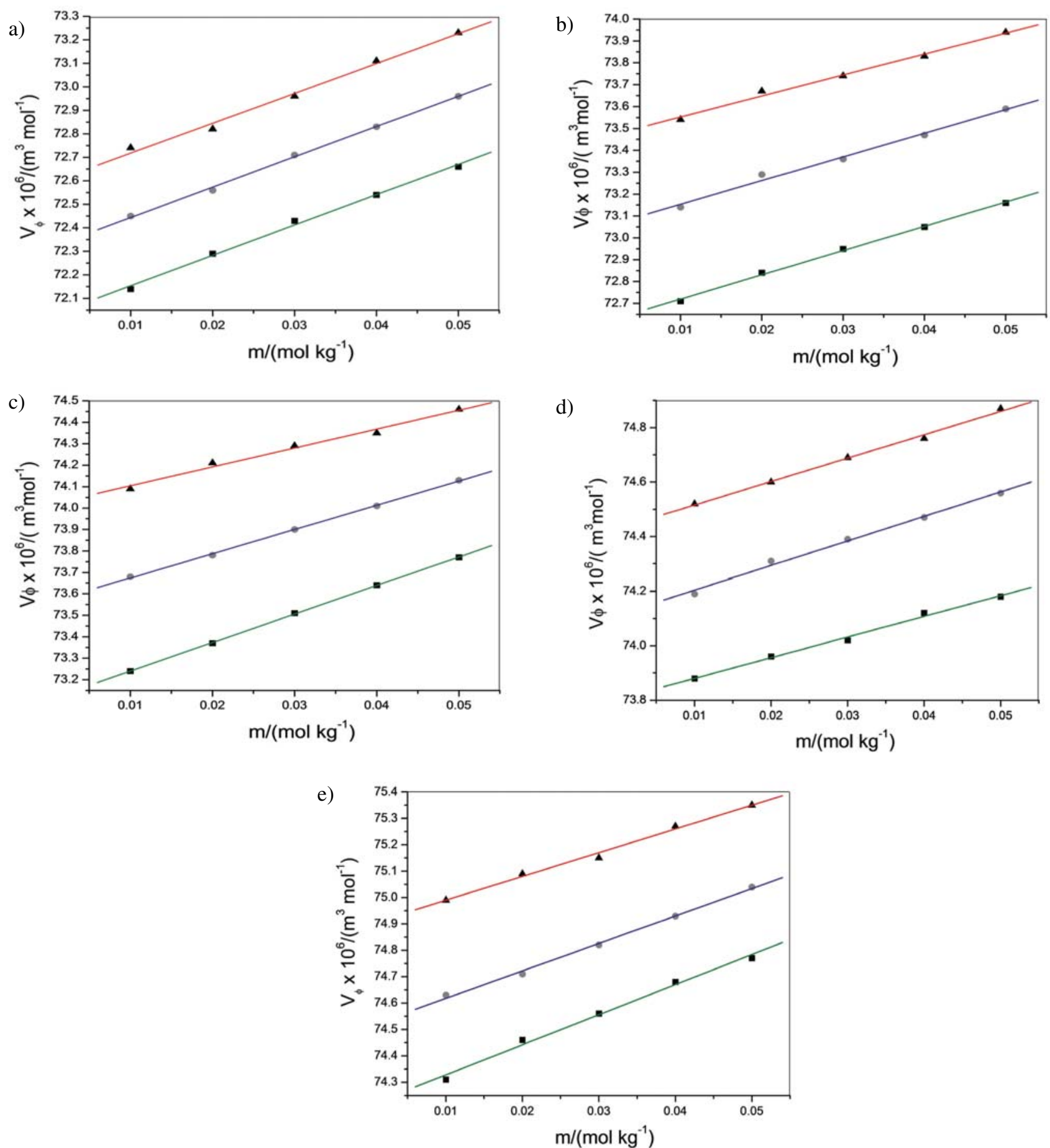

Figure 1. Variation of apparent molar volume versus molality of Asp in aqueous and aqueous + PD solutions: (a) water, (b) 5\% PD, (c) 10\% PD, (d) 15\% PD and (e) 20\% PD at temperatures, $T / \mathrm{K}=298.15(\boldsymbol{\square})$; $303.15(\bullet) ; 308.15(\boldsymbol{\Delta})$.

\section{1. 2. Partial molar Volume of Transfer}

The partial molar volume of transfer, $\mathrm{V}_{\phi, t r}^{0}$, of Asp from aqueous to aqueous PD solution has been calculated using Eq. (3).

$$
\mathrm{V}_{\phi, t r}^{0}=\mathrm{V}_{\phi}^{0}(\mathrm{aq}-\mathrm{PD} \text { solution })-\mathrm{V}_{\phi}^{0}(\mathrm{aq})
$$

where $\mathrm{V}_{\phi}^{0}(\mathrm{aq})$ is the limiting apparent molar volume of Asp in aqueous medium (Table 2). The $\mathrm{V}_{\phi}^{0}$ of an amino acid can be considered $a^{25}$ :

$$
\mathrm{V}_{\phi=}^{0} \mathrm{~V}_{\mathrm{vw}}+\mathrm{V}_{\text {void }}+\mathrm{V}_{\text {shrinkage }}
$$

where $\mathrm{V}_{\text {shrinkage }}$ is shrinkage in volume due to solvent-sol- 
Table 1. Densities, $\rho$, and apparent molar volumes, $\mathrm{V}_{\phi}$, of solutions of Asp in aqueous and aqueous-PD (5, 10,15 and 20\%, PD w/w in water) as function of molality, $\mathrm{m}$, of Asp at different temperatures.

\begin{tabular}{|c|c|c|c|c|c|c|}
\hline \multirow[t]{2}{*}{$\overline{\mathrm{m} /\left(\mathrm{mol} \mathrm{kg}^{-1}\right)}$} & \multicolumn{3}{|c|}{$\rho /\left(\mathrm{kg} \mathrm{m}^{-3}\right)$} & \multicolumn{3}{|c|}{$\mathrm{V}_{\phi} \times 10^{6} /\left(\mathrm{m}^{3} \mathrm{~mol}^{-1}\right)$} \\
\hline & 298.15 K & $303.15 \mathrm{~K}$ & 308.15 K & 298.15 K & $303.15 \mathrm{~K}$ & $308.15 \mathrm{~K}$ \\
\hline \multicolumn{7}{|c|}{ Asp in aqueous } \\
\hline 0.00 & 1005.148 & 1003.655 & 1002.002 & & & \\
\hline 0.01 & 1005.756 & 1004.260 & 1002.605 & 72.14 & 72.45 & 72.74 \\
\hline 0.02 & 1006.361 & 1004.863 & 1003.205 & 72.29 & 72.56 & 72.82 \\
\hline 0.03 & 1006.963 & 1005.461 & 1003.801 & 72.43 & 72.71 & 72.96 \\
\hline 0.04 & 1007.560 & 1006.056 & 1004.393 & 72.54 & 72.83 & 73.11 \\
\hline 0.05 & 1008.155 & 1006.648 & 1004.983 & 72.66 & 72.96 & 73.23 \\
\hline \multicolumn{7}{|c|}{ Asp in $5 \%$ aqueous-PD } \\
\hline 0.00 & 1008.396 & 1006.824 & 1005.024 & & & \\
\hline 0.01 & 1008.998 & 1007.422 & 1005.618 & 72.71 & 73.14 & 73.54 \\
\hline 0.02 & 1009.597 & 1008.016 & 1006.209 & 72.84 & 73.29 & 73.67 \\
\hline 0.03 & 1010.193 & 1008.609 & 1006.798 & 72.95 & 73.36 & 73.74 \\
\hline 0.04 & 1010.786 & 1009.198 & 1007.384 & 73.05 & 73.47 & 73.83 \\
\hline 0.05 & 1011.376 & 1009.783 & 1007.967 & 73.16 & 73.59 & 73.94 \\
\hline \multicolumn{7}{|c|}{ Asp in $10 \%$ aqueous-PD } \\
\hline 0.00 & 1011.533 & 1009.832 & 1008.014 & & & \\
\hline 0.01 & 1012.129 & 1010.424 & 1008.602 & 73.24 & 73.68 & 74.09 \\
\hline 0.02 & 1012.722 & 1011.013 & 1009.187 & 73.37 & 73.78 & 74.21 \\
\hline 0.03 & 1013.311 & 1011.599 & 1009.770 & 73.51 & 73.90 & 74.29 \\
\hline 0.04 & 1013.897 & 1012.182 & 1010.351 & 73.64 & 74.01 & 74.35 \\
\hline 0.05 & 1014.479 & 1012.761 & 1010.928 & 73.77 & 74.13 & 74.46 \\
\hline \multicolumn{7}{|c|}{ Asp in $15 \%$ aqueous-PD } \\
\hline 0.00 & 1015.324 & 1013.487 & 1011.458 & & & \\
\hline 0.01 & 1015.913 & 1014.073 & 1012.041 & 73.88 & 74.19 & 74.52 \\
\hline 0.02 & 1016.500 & 1014.656 & 1012.622 & 73.96 & 74.31 & 74.60 \\
\hline 0.03 & 1017.085 & 1015.237 & 1013.200 & 74.02 & 74.39 & 74.69 \\
\hline 0.04 & 1017.666 & 1015.816 & 1013.776 & 74.12 & 74.47 & 74.76 \\
\hline 0.05 & 1018.246 & 1016.391 & 1014.348 & 74.18 & 74.56 & 74.87 \\
\hline \multicolumn{7}{|c|}{ Asp in $20 \%$ aqueous-PD } \\
\hline 0.00 & 1018.722 & 1016.786 & 1014.614 & & & \\
\hline 0.01 & 1019.306 & 1017.367 & 1015.192 & 74.31 & 74.63 & 74.99 \\
\hline 0.02 & 1019.886 & 1017.946 & 1015.767 & 74.46 & 74.71 & 75.09 \\
\hline 0.03 & 1020.464 & 1018.521 & 1016.340 & 74.56 & 74.82 & 75.15 \\
\hline 0.04 & 1021.038 & 1019.093 & 1016.909 & 74.68 & 74.93 & 75.27 \\
\hline 0.05 & 1021.610 & 1019.662 & 1017.476 & 74.77 & 75.04 & 75.35 \\
\hline
\end{tabular}

Table 2. Limiting apparent molar volumes, $\mathrm{V}_{\phi}^{0}$, experimental slopes, $\mathrm{S}_{\mathrm{v}}$, and standard deviations of linear regression (in parenthesis) of Asp in aqueous and aqueous solution of PD at different temperatures.

\begin{tabular}{|c|c|c|c|c|c|c|}
\hline \multirow{2}{*}{ System } & \multicolumn{3}{|c|}{$\mathrm{V}^{0} \times 10^{6} /\left(\mathrm{m}^{3} \mathrm{~mol}^{-1}\right)$} & \multicolumn{3}{|c|}{$\mathrm{S}_{\mathrm{y}} \times 10^{6} /\left(\mathrm{m}^{3} \mathrm{~mol}^{-2} \mathrm{~kg}\right)$} \\
\hline & $298.15 \mathrm{~K}$ & $303.15 \mathrm{~K}$ & $308.15 \mathrm{~K}$ & $298.15 \mathrm{~K}$ & $303.15 \mathrm{~K}$ & $308.15 \mathrm{~K}$ \\
\hline \multirow[t]{2}{*}{ Asp in aqueous } & $72.02( \pm 0.015)$ & $72.31( \pm 0.009)$ & $72.59( \pm 0.225)$ & $12.9( \pm 0.470)$ & $12.9( \pm 0.300)$ & $12.7( \pm 0.680)$ \\
\hline & $72.30( \pm 0.040)^{19}$ & & $73.23( \pm 0.020)^{19}$ & & & \\
\hline Asp in $5 \%$ aqueous-PD & $72.60( \pm 0.009)$ & $73.04( \pm 0.020)$ & $73.45( \pm 0.016)$ & $11.1( \pm 0.302)$ & $10.8( \pm 0.621)$ & $9.6( \pm 0.503)$ \\
\hline Asp in $10 \%$ aqueous-PD & $73.10( \pm 0.003)$ & $73.56( \pm 0.006)$ & $74.01( \pm 0.018)$ & $13.3( \pm 0.101)$ & $11.3( \pm 0.191)$ & $8.8( \pm 0.565)$ \\
\hline Asp in $15 \%$ aqueous-PD & $73.80( \pm 0.010)$ & $74.11( \pm 0.013)$ & $74.43( \pm 0.010)$ & $7.6( \pm 0.326)$ & $9.0( \pm 0.416)$ & $8.6( \pm 0.326)$ \\
\hline Asp in $20 \%$ aqueous-PD & $74.21( \pm 0.018)$ & $74.51( \pm 0.011)$ & $74.90( \pm 0.014)$ & $11.4( \pm 0.565)$ & $10.4( \pm 0.346)$ & $9.0( \pm 0.447)$ \\
\hline
\end{tabular}

vent interactions, $\mathrm{V}_{\text {void }}$ is contribution due to voids and $\mathrm{V}_{\mathrm{vw}}$ is van der Waals volume. The contribution of first two terms in Eq. (4) is believed to be approximately same in water and also in mixed aqueous solutions. Hence, the positive volume of transfer for Asp may be rationalized in terms of a decrease in the volume of shrinkage. This means few water molecules in the vicinity of the Asp may be released to the bulk water in presence of PD. In general, the types of interactions occurring between Asp and PD may be classified as follows: ${ }^{26,27}$ 
a) ionic-hydrophilic interactions between $-\mathrm{NH}_{3}{ }^{+}$and $-\mathrm{COO}^{-}$head groups of Asp and -OH group of PD

b) hydrophilic-hydrophilic interactions between $-\mathrm{CH}_{2} \mathrm{COOH}$ group of Asp and -OH group of PD

c) ionic-hydrophobic interactions between $-\mathrm{NH}_{3}{ }^{+}$and $-\mathrm{COO}^{-}$head groups of Asp and methyl group of PD

d) hydrophilic-hydrophobic interactions between $-\mathrm{OH}$ group of $\mathrm{PD}$ and $-\mathrm{CH}_{2}$ group of Asp, and

Table 3. Partial molar volumes of transfer, $\mathrm{V}_{\phi, \mathrm{tr}}^{0} \times 10^{6} /\left(\mathrm{m}^{3} \mathrm{~mol}^{-1}\right)$, of Asp in aqueous solution of PD at different temperatures.

\begin{tabular}{lccc}
\hline System & $\mathbf{2 9 8 . 1 5 ~ K}$ & $\mathbf{3 0 3 . 1 5 ~ K}$ & $\mathbf{3 0 8 . 1 5 ~ K}$ \\
\hline Asp in 5\% aqueous-PD & 0.58 & 0.73 & 0.86 \\
Asp in 10\% aqueous-PD & 1.08 & 1.25 & 1.42 \\
Asp in 15\% aqueous-PD & 1.78 & 1.80 & 1.84 \\
Asp in 20\% aqueous-PD & 2.19 & 2.20 & 2.31 \\
\hline
\end{tabular}

e) hydrophobic-hydrophobic interactions between $-\mathrm{CH}_{2}$ group of Asp and the methyl group of PD.

The positive values of partial molar volume of transfer indicate that interactions of types (a) and (b), mentioned above, predominates due to reduction in electrostriction effect and enhancement of overall structure of water. Furthermore, the values of partial molar volume of transfer increase with increase in concentration of PD in the solution as shown in Table 3. This may be due to greater ionic-hydrophilic and hydrophilic-hydrophilic group interactions with increased concentration of PD. The explanation lies in the fact that the $-\mathrm{OH}$ group of $\mathrm{PD}$ is highly polar; it has a strong electron-pair donating ability which is capable of forming $\mathrm{HO} \cdots \mathrm{HOOC}$ hydrogen bond with the side group of Asp. With the increasing concentration of PD, the probability of forming hydrogen bond increases and, hence, favoring the ionic-hydrophilic

Table 4. Speeds of sound, $u$, and apparent molar isentropic compressibilities, $\mathrm{K}_{\mathrm{\phi}, \mathrm{s},}$ of Asp in aqueous and aqueous-PD (5, 10,15 and $20 \%, \mathrm{PD} w / \mathrm{w}$ in water) as function of molality, $\mathrm{m}$, of Asp at different temperatures.

\begin{tabular}{|c|c|c|c|c|c|c|}
\hline \multirow{2}{*}{$\mathbf{m} /\left(\mathbf{m o l ~ k g}^{-1}\right)$} & \multicolumn{3}{|c|}{$\mathbf{u} /\left(\mathrm{m} \mathrm{s}^{-1}\right)$} & \multicolumn{3}{|c|}{$\mathrm{K}_{\phi \mathrm{s}} \times 10^{15} /\left(\mathrm{m}^{3} \mathrm{~mol}^{-1} \mathrm{~Pa}^{-1}\right)$} \\
\hline & $298.15 \mathrm{~K}$ & $303.15 \mathrm{~K}$ & $308.15 \mathrm{~K}$ & 298.15 K & $303.15 \mathrm{~K}$ & $308.15 \mathrm{~K}$ \\
\hline \multicolumn{7}{|l|}{ Asp in aqueous } \\
\hline 0.00 & 1497.76 & 1510.50 & 1520.80 & & & \\
\hline 0.01 & 1498.29 & 1511.03 & 1521.33 & -25.82 & -25.17 & -24.54 \\
\hline 0.02 & 1498.81 & 1511.55 & 1521.86 & -25.47 & -24.66 & -24.13 \\
\hline 0.03 & 1499.32 & 1512.05 & 1522.35 & -25.05 & -24.04 & -23.52 \\
\hline 0.04 & 1499.82 & 1512.54 & 1522.85 & -24.59 & -23.54 & -23.14 \\
\hline 0.05 & 1500.30 & 1513.02 & 1523.32 & -24.04 & -23.07 & -22.52 \\
\hline \multicolumn{7}{|c|}{ Asp in 5\% aqueous-PD } \\
\hline 0.00 & 1524.62 & 1533.33 & 1543.52 & & & \\
\hline 0.01 & 1525.14 & 1533.85 & 1544.04 & -23.05 & -22.46 & -21.84 \\
\hline 0.02 & 1525.65 & 1534.36 & 1544.55 & -22.69 & -21.99 & -21.44 \\
\hline 0.03 & 1526.15 & 1534.85 & 1545.04 & -22.27 & -21.49 & -20.91 \\
\hline 0.04 & 1526.64 & 1535.33 & 1545.52 & -21.89 & -21.03 & -20.45 \\
\hline 0.05 & 1527.12 & 1535.79 & 1545.98 & -21.51 & -20.46 & -19.93 \\
\hline \multicolumn{7}{|c|}{ Asp in $10 \%$ aqueous-PD } \\
\hline 0.00 & 1562.03 & 1568.23 & 1573.04 & & & \\
\hline 0.01 & 1562.55 & 1568.74 & 1573.55 & -20.50 & -19.67 & -19.22 \\
\hline 0.02 & 1563.06 & 1569.24 & 1574.04 & -20.15 & -19.27 & -18.67 \\
\hline 0.03 & 1563.56 & 1569.72 & 1574.52 & -19.78 & -18.73 & -18.23 \\
\hline 0.04 & 1564.04 & 1570.19 & 1574.98 & -19.27 & -18.29 & -17.74 \\
\hline 0.05 & 1564.52 & 1570.65 & 1575.43 & -18.92 & -17.87 & -17.30 \\
\hline \multicolumn{7}{|c|}{ Asp in $15 \%$ aqueous-PD } \\
\hline 0.00 & 1586.35 & 1590.26 & 1594.38 & & & \\
\hline 0.01 & 1586.86 & 1590.75 & 1594.86 & -18.18 & -17.05 & -16.31 \\
\hline 0.02 & 1587.35 & 1591.23 & 1595.32 & -17.65 & -16.64 & -15.78 \\
\hline 0.03 & 1587.83 & 1591.69 & 1595.77 & -17.26 & -16.19 & -15.37 \\
\hline 0.04 & 1588.29 & 1592.13 & 1596.20 & -16.77 & -15.67 & -14.89 \\
\hline 0.05 & 1588.73 & 1592.56 & 1596.61 & -16.34 & -15.23 & -14.36 \\
\hline \multicolumn{7}{|c|}{ Asp in $20 \%$ aqueous-PD } \\
\hline 0.00 & 1610.27 & 1613.13 & 1616.44 & & & \\
\hline 0.01 & 1610.75 & 1613.59 & 1616.89 & -15.27 & -14.20 & -13.63 \\
\hline 0.02 & 1611.21 & 1614.03 & 1617.33 & -14.71 & -13.67 & -13.27 \\
\hline 0.03 & 1611.66 & 1614.46 & 1617.75 & -14.33 & -13.28 & -12.83 \\
\hline 0.04 & 1612.10 & 1614.87 & 1618.16 & -13.96 & -12.81 & -12.40 \\
\hline 0.05 & 1612.52 & 1615.28 & 1618.56 & -13.52 & -12.46 & -12.05 \\
\hline
\end{tabular}


interaction between $\mathrm{COOH}$ of $\mathrm{Asp}$ and $\mathrm{OH}$ group of PD and hydrophilic-hydrophilic interaction between $\mathrm{CH}_{2} \mathrm{COOH}$ of Asp and $\mathrm{OH}$ group of $\mathrm{PD}$ which results in the large partial molar volume of transfer of Asp in PD solution.
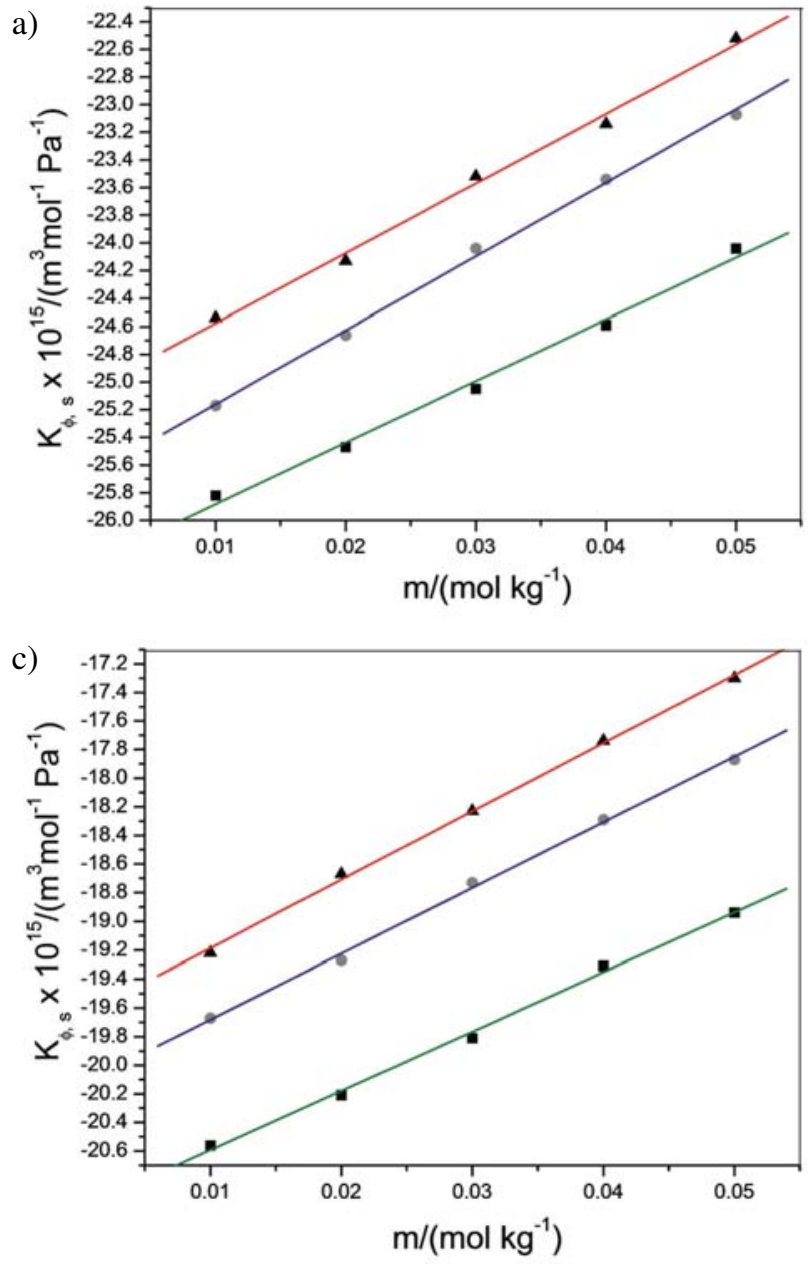

\section{2. Apparent Molar Isentropic Compressibility}

The experimental values of speed of sound of solution of Asp in aqueous and 5\%,10\%,15\% and 20\% aqueous solutions of PD have also measured at aforementioned
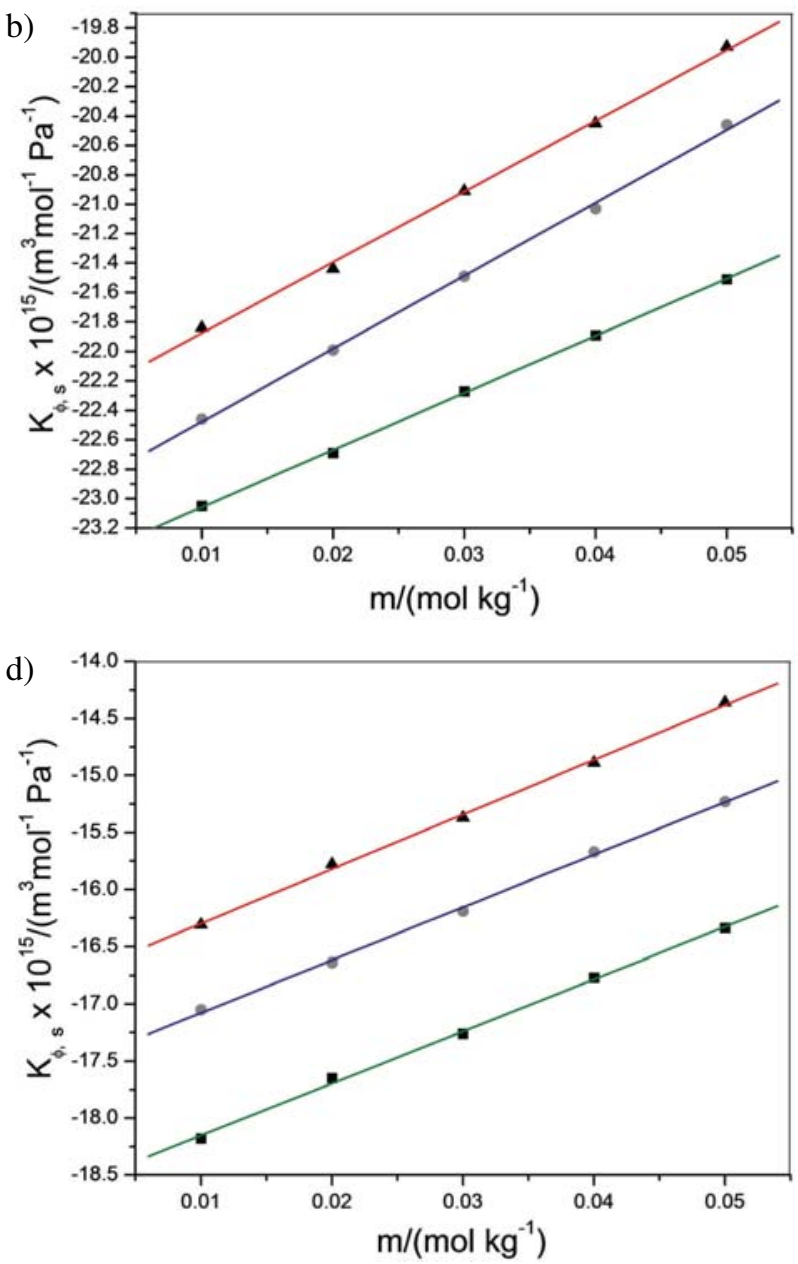

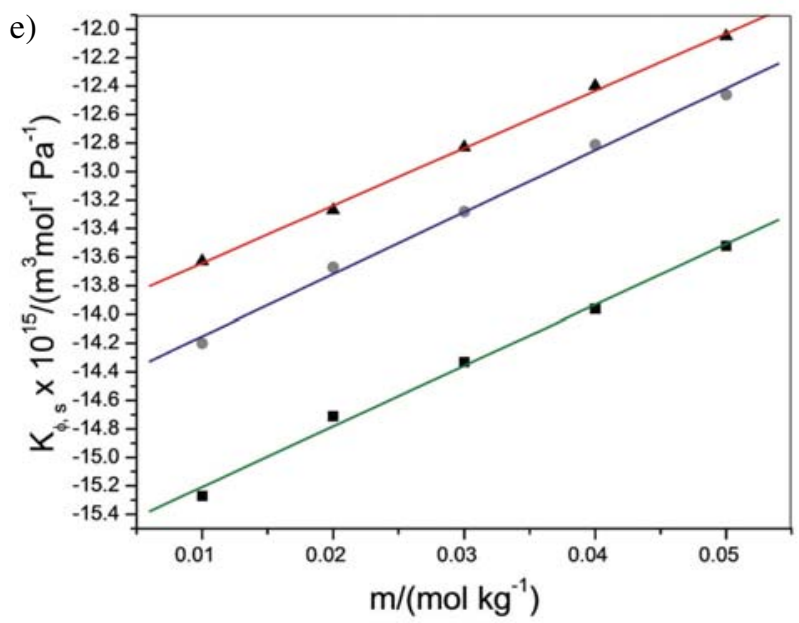

Figure 2. Variation of apparent molar isentropic compressibility versus molality of Asp in aqueous and aqueous + PD solutions: (a)

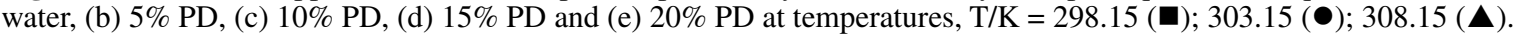


temperatures in order to evaluate apparent molar isentropic compressibilities, $\mathrm{K}_{\phi, \mathrm{s}}$, using Eq. (5).

$$
\mathrm{K}_{\phi, \mathrm{s}}=\left(\mathrm{Mk}_{\mathrm{s}} / \rho\right)-\left[\left(\mathrm{k}_{\mathrm{s}}^{\mathrm{o}} \rho-\mathrm{k}_{\mathrm{s}} \rho_{\mathrm{o}}\right) / \mathrm{m} \rho \rho_{\mathrm{o}}\right]
$$

where $\mathrm{k}_{\mathrm{s}}$ and $\mathrm{k}_{\mathrm{s}}^{0}$ are isentropic compressibilities of solution and solvent, respectively, calculated using speed of sound $(\mathrm{u})$ relation:

$$
\mathrm{k}_{\mathrm{s}}=1 /\left(\mathrm{u}^{2} \rho\right)
$$

The plot between $\mathrm{K}_{\phi, \mathrm{s}}$ and molality (Fig. 2) are found to be linear at each temperature. The magnitude of negative values of $\mathrm{K}_{\phi, s}$ decreases both with increase in temperature as well as concentration of PD in aqueous medium. The negative $\mathrm{K}_{\phi, \mathrm{s}}$ values shows that water molecules around solute are less compressible than those in the bulk which is attributed to strong attractive interactions. ${ }^{28,29}$

\section{2. 1. Limiting Apparent Molar Isentropic Compressibility}

The variation of apparent molar isentropic compressibility with the molality can be adequately represented by Eq. (7).

$$
\mathrm{K}_{\phi}, \mathrm{K}_{\phi}^{0}{ }_{\phi \mathrm{s}}+\mathrm{S}_{\mathrm{k}} \mathrm{m}
$$

where $\mathrm{K}_{\phi, \mathrm{s}}^{0}$ is limiting apparent molar isentropic compressibility, which is also referred to as partial molar isentropic compressibility, and is a measure of solute-solvent interaction. $\mathrm{S}_{\mathrm{k}}$ is the experimental slope; an indicative of solute-solute interactions. The values of $\mathrm{K}_{\phi, s}^{0}, \mathrm{~S}_{\mathrm{k}}$ together with their standard errors are shown in Table 5.

The computed values of $\mathrm{K}_{\phi, \mathrm{s}}^{0}$ which come out to be negative, become less negative with increase in concentration as well as temperature. The negative values of $\mathrm{K}_{\phi}^{0}$,s (loss of compressibility of medium) indicate that the water molecules surrounding the amino acids would present greater resistance to compression than bulk. With increase in temperature, the values become less negative which means that electrostriction interaction between amino acids and water molecules are suppressed due to formation of ion pairs between ions of PD and Asp, and some water molecules are released to bulk. In other words, the more negative values of $\mathrm{K}_{\phi, s}^{0}$ reflect strong solute-solvent interactions attributed to electrostatic interactions between Asp and solvent which makes the solution rather incompressible. An irregular trend of $\mathrm{S}_{\mathrm{k}}$ is governed by number of effects which also suggest the presence of solute-solute interactions in the system.

\section{2. 2. Partial Molar Compressibility of Transfer}

The partial molar compressibility of transfer $\left(\mathrm{K}_{\phi, \mathrm{s}, \mathrm{tr}}^{0}\right)$ of Asp from aqueous to aqueous PD solutions has been calculated using the following relation.

$$
\mathrm{K}_{\phi, \mathrm{s}, \mathrm{tr}}^{0}=\mathrm{K}_{\phi, \mathrm{s}}^{0}(\mathrm{aq}-\mathrm{PD} \text { solution })-\mathrm{K}_{\phi, \mathrm{s}}^{0}(\mathrm{aq})
$$

where $\mathrm{K}_{\phi, \mathrm{s}}^{0}(\mathrm{aq})$ is the limiting apparent molar isentropic compressibility of Asp in aqueous medium (Table 5).

The values of partial molar compressibility of transfer $\mathrm{K}_{\phi, s, \mathrm{r}}^{0}$, as reported in Table 6 , are positive which increase with increase in concentration of PD. The positive values indicate the dominance of the charged end groups $\mathrm{NH}_{3}{ }^{+}$and $\mathrm{COO}^{-}$. The interactions between $\mathrm{PD}$ and the zwitterionic center of Asp increase with increasing PD concentration due to structure-making tendency of the ions and decrease in electrostriction. As a result, the electrostricted water is much less compressible than bulk water giving rise to a large decrease in the compressibility with increase in the PD concentration. Thus the $\mathrm{K}_{\phi, \mathrm{s}}$ values are negative and $\mathrm{K}_{\phi, \mathrm{s}, \mathrm{tr}}^{0}$ values are positive for Asp.

It is important to mention here that on addition of Asp to the co-solute there is decrease in the $\mathrm{pH}$ of solution, and the side chains of the acidic amino acids remain fully deprotonated. ${ }^{19}$ Thus, the amino acid studied mainly exists in zwitterionic form in co-solute solutions and their side chains remain fully deprotonated due to hydrolysis. Thus, deprotonated amino acid interacts strongly with aqueous solvent resulting in increase in apparent molar volume, $\mathrm{V}_{\phi}$ which in turn leads to increase in limiting apparent molar volume, $\mathrm{V}_{\phi}^{0}$. A similar increasing trend is shown by all other investigated thermodynamic properties.

It is well known that the acid group on the side chain of Asp undergoes ionization in water to small extent, i.e., 5 to $8 \%$, to give a small fraction of L-aspartate ions along

\begin{tabular}{|c|c|c|c|c|c|c|}
\hline \multirow{2}{*}{ System } & \multicolumn{3}{|c|}{$\mathrm{K}_{\phi \mathrm{s}}^{0} \times 10^{15} /\left(\mathrm{m}^{3} \mathrm{~mol}^{-1} \mathrm{~Pa}^{-1}\right)$} & \multicolumn{3}{|c|}{$\mathrm{S}_{\mathrm{k}} \times 10^{15} /\left(\mathrm{m}^{3} \mathrm{~mol}^{-2} \mathrm{~Pa}^{-1} \mathrm{~kg}\right)$} \\
\hline & $298.15 \mathrm{~K}$ & 303.15 K & $308.15 \mathrm{~K}$ & $5 \mathrm{~K}^{\mathrm{n}}$ & $303.15 \mathrm{~K}$ & 308. \\
\hline & $26.32( \pm 0.071)$ & $-25.70( \pm 0.047)$ & -25.08 & $4.4( \pm 2.157)$ & $53.2( \pm 1.446)$ & $50.3( \pm 2.184)$ \\
\hline As & $.015)$ & $-22.97( \pm 0.034)$ & -22.35 & $.461)$ & $49.6( \pm$ & 170) \\
\hline & $-21.00( \pm 0.046)$ & $-20.14( \pm 0.040)$ & -19.66 & $\pm 1.385)$ & $45.8( \pm 1.194)$ & 47.7( \\
\hline & $.036)$ & $-17.54( \pm 0.03$ & -16.78 & 1.101) & $46.1( \pm 1.018)$ & $47.9( \pm 1.135)$ \\
\hline Asp in $20 \%$ aqueous-PD & $-15.63( \pm 0.063)$ & $-14.58( \pm 0.054)$ & $-14.04( \pm 0.031)$ & $42.5( \pm 1.900)$ & $43.4( \pm 1.650)$ & $40.3( \pm 0.936)$ \\
\hline
\end{tabular}
with their unionized form. The values reported in litera-

Table 5. Limiting apparent molar isentropic compressibilities, $\mathrm{K}_{\phi, \mathrm{s}}^{0}$, experimental slopes, $\mathrm{S}_{\mathrm{k}}$, and standard deviations of linear regression (in parenthesis) of Asp in aqueous and aqueous solution of PD at different temperatures. 
Table 6. Partial molar compressibilities of transfer, $\mathrm{K}_{\phi}^{0}{ }_{\mathrm{s}, \mathrm{tr}}, \times$ $10^{15} /\left(\mathrm{m}^{3} \mathrm{~mol}^{-1} \mathrm{~Pa}^{-1}\right)$, of Asp in aqueous solution of PD at different temperatures.

\begin{tabular}{lccc}
\hline System & $\mathbf{2 9 8 . 1 5 ~ K}$ & $\mathbf{3 0 3 . 1 5 ~ K}$ & $\mathbf{3 0 8 . 1 5 ~ K}$ \\
\hline Asp in 5\% aqueous-PD & 2.88 & 2.72 & 2.73 \\
Asp in 10\% aqueous-PD & 5.32 & 5.55 & 5.42 \\
Asp in 15\% aqueous-PD & 7.72 & 8.16 & 8.30 \\
Asp in 20\% aqueous-PD & 9.55 & 11.11 & 11.04 \\
\hline
\end{tabular}

ture for limiting apparent molar volume, $\mathrm{V}_{\phi}^{0}$, of aqueous solution of $\mathrm{Asp}^{30}$ at $298.15 \mathrm{~K}$ is 74.78 when ionization of Asp is considered. Since we have not considered the ionization correction, our value of limiting apparent molar volume comes out to be 72.02 which is in close agreement with literature value of 72.30 evaluated without taking into account the ionization correction factor. ${ }^{19}$ It is also not- ed that the value for this system at $298.15 \mathrm{~K}$ reported by Jolicoeur et.al. ${ }^{31}\left(\mathrm{~V}_{\phi}^{0}=71.79\right)$ is also in excellent agreement with our value. The contributions due to ionization or protonation of side chain groups were considered negligible in the concentration ranges investigated. The zwitterionic structure (terminal- $\mathrm{NH}_{2}, \mathrm{COOH}$ groups) is assumed predominant in this amino acid.

\section{3. Viscosity}

The viscosities of Asp in aqueous and 5\%, 10\%, $15 \%$ and $20 \%$ aqueous solutions of PD were also measured at $T=298.15,303.15$ and $308.15 \mathrm{~K}$ (Table 7). The variation of relative viscosity which is calculated as the ratio of viscosity of solution, $\eta$, and corresponding solvent, $\eta_{\mathrm{o}}$, i.e., $\eta_{\mathrm{r}}=\eta / \eta_{\mathrm{o}}$, (Table 7 ) can be represented by ${ }^{32}$ Jones-Dole equation:

Table 7. Viscosities, $\eta$, and relative viscosities, $\eta_{\mathrm{r}}$, of Asp in aqueous and aqueous-PD (5, 10, 15 and 20\%, PD w/w in water) as function of molarity, C, of Asp at different temperatures.

\begin{tabular}{|c|c|c|c|c|c|c|c|c|}
\hline$\overline{\mathrm{C} /\left(\mathrm{mol} \mathrm{L}^{-1}\right)}$ & $\begin{array}{c}\eta \times 10^{3} /(\text { Pa s }) \\
298.15 \mathrm{~K}\end{array}$ & $\eta_{\mathrm{r}}$ & $\mathrm{C} /\left(\mathrm{mol} \mathrm{L}^{-1}\right)$ & $\begin{array}{c}\eta \times 10^{3} /(\text { Pa s }) \\
303.15 \mathrm{~K}\end{array}$ & $\eta_{\mathrm{r}}$ & $\mathrm{C} /\left(\mathbf{m o l ~ L}^{1}\right)$ & $\begin{array}{c}\eta \times 10^{3} /(\text { Pa s) } \\
308.15 \mathrm{~K}\end{array}$ & $\eta_{\mathrm{r}}$ \\
\hline \multicolumn{9}{|c|}{ Asp in aqueous } \\
\hline 0.00000 & 0.9163 & & 0.00000 & 0.8241 & & 0.00000 & 0.7412 & \\
\hline 0.01005 & 0.9186 & 1.0025 & 0.01004 & 0.8259 & 1.0021 & 0.01002 & 0.7424 & 1.0016 \\
\hline 0.02011 & 0.9206 & 1.0046 & 0.02009 & 0.8277 & 1.0043 & 0.02005 & 0.7442 & 1.0040 \\
\hline 0.03019 & 0.9229 & 1.0072 & 0.03016 & 0.8297 & 1.0068 & 0.03011 & 0.7460 & 1.0064 \\
\hline 0.04030 & 0.9254 & 1.0099 & 0.04024 & 0.8318 & 1.0093 & 0.04017 & 0.7477 & 1.0087 \\
\hline 0.05040 & 0.9277 & 1.0124 & 0.05036 & 0.8338 & 1.0117 & 0.05024 & 0.7494 & 1.0110 \\
\hline \multicolumn{9}{|c|}{ Asp in 5\% aqueous-PD } \\
\hline 0.00000 & 0.9957 & & 0.00000 & 0.9221 & & 0.00000 & 0.8286 & \\
\hline 0.01008 & 0.9990 & 1.0033 & 0.01007 & 0.9248 & 1.0029 & 0.01005 & 0.8306 & 1.0024 \\
\hline 0.02019 & 1.0016 & 1.0059 & 0.02016 & 0.9272 & 1.0055 & 0.02005 & 0.8329 & 1.0051 \\
\hline 0.03030 & 1.0046 & 1.0089 & 0.03025 & 0.9299 & 1.0084 & 0.03011 & 0.8352 & 1.0079 \\
\hline 0.04043 & 1.0074 & 1.0117 & 0.04036 & 0.9324 & 1.0111 & 0.04017 & 0.8374 & 1.0105 \\
\hline 0.05056 & 1.0103 & 1.0146 & 0.05051 & 0.9350 & 1.0139 & 0.05024 & 0.8396 & 1.0132 \\
\hline \multicolumn{9}{|c|}{ Asp in $10 \%$ aqueous-PD } \\
\hline 0.00000 & 1.0623 & & 0.00000 & 0.9999 & & 0.00000 & 0.9352 & \\
\hline 0.01012 & 1.0664 & 1.0038 & 0.01011 & 1.0032 & 1.0033 & 0.01008 & 0.9380 & 1.0029 \\
\hline 0.02025 & 1.0695 & 1.0067 & 0.02023 & 1.0062 & 1.0063 & 0.02018 & 0.9408 & 1.0059 \\
\hline 0.03039 & 1.0731 & 1.0101 & 0.03036 & 1.0094 & 1.0095 & 0.03029 & 0.9436 & 1.0089 \\
\hline 0.04055 & 1.0766 & 1.0134 & 0.04051 & 1.0126 & 1.0127 & 0.04041 & 0.9466 & 1.0121 \\
\hline 0.05072 & 1.0800 & 1.0166 & 0.05069 & 1.0158 & 1.0159 & 0.05054 & 0.9495 & 1.0152 \\
\hline \multicolumn{9}{|c|}{ Asp in $15 \%$ aqueous-PD } \\
\hline 0.00000 & 1.2434 & & 0.00000 & 1.1548 & & 0.00000 & 1.0593 & \\
\hline 0.01016 & 1.2489 & 1.0044 & 0.01014 & 1.1595 & 1.0040 & 0.01012 & 1.0064 & 1.0036 \\
\hline 0.02032 & 1.2530 & 1.0077 & 0.02029 & 1.1633 & 1.0073 & 0.02025 & 1.0667 & 1.0069 \\
\hline 0.03051 & 1.2575 & 1.0113 & 0.03045 & 1.1672 & 1.0107 & 0.03039 & 1.0700 & 1.0101 \\
\hline 0.04070 & 1.2620 & 1.0149 & 0.04063 & 1.1714 & 1.0143 & 0.04055 & 1.0740 & 1.0138 \\
\hline 0.05091 & 1.2660 & 1.0181 & 0.05084 & 1.1749 & 1.0174 & 0.05071 & 1.0770 & 1.0167 \\
\hline \multicolumn{9}{|c|}{ Asp in $20 \%$ aqueous-PD } \\
\hline 0.00000 & 1.4053 & & 0.00000 & 1.3067 & & 0.00000 & 1.2156 & \\
\hline 0.01019 & 1.4125 & 1.0051 & 0.01017 & 1.3129 & 1.0047 & 0.01015 & 1.2209 & 1.0043 \\
\hline 0.02039 & 1.4174 & 1.0086 & 0.02036 & 1.3175 & 1.0082 & 0.02031 & 1.2250 & 1.0077 \\
\hline 0.03061 & 1.4232 & 1.0127 & 0.03057 & 1.3226 & 1.0121 & 0.03049 & 1.2296 & 1.0115 \\
\hline 0.04084 & 1.4284 & 1.0164 & 0.04078 & 1.3274 & 1.0158 & 0.04067 & 1.2341 & 1.0152 \\
\hline 0.05108 & 1.4344 & 1.0207 & 0.05103 & 1.3300 & 1.0178 & 0.05087 & 1.2391 & 1.0193 \\
\hline
\end{tabular}




$$
\eta_{\mathrm{r}}=\eta / \eta_{\mathrm{o}}=1+A \mathrm{C}^{1 / 2}+\mathrm{BC}
$$

where A and B are the Falkenhagen and viscosity B-coeffients, respectively. The former specifies interactions between solute-solute ${ }^{33,34}$ while the later is a measure of

a)

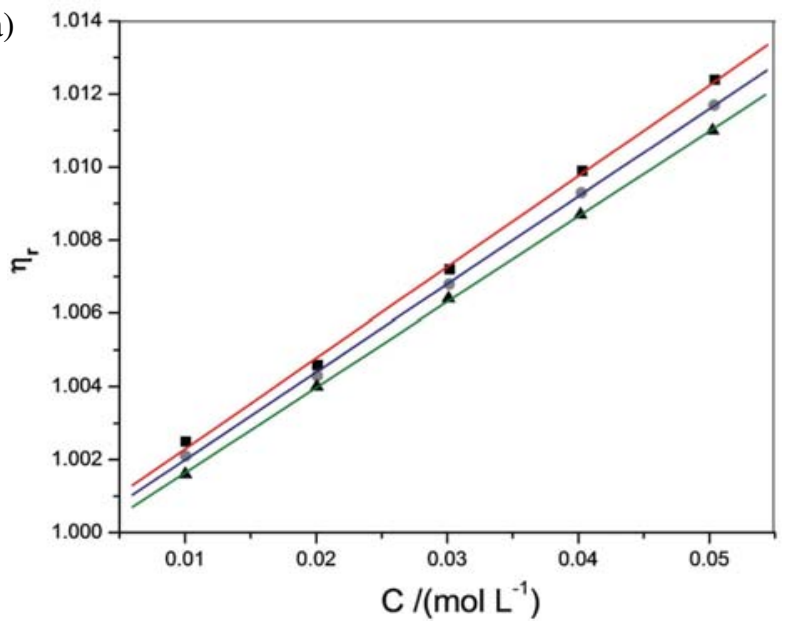

c)

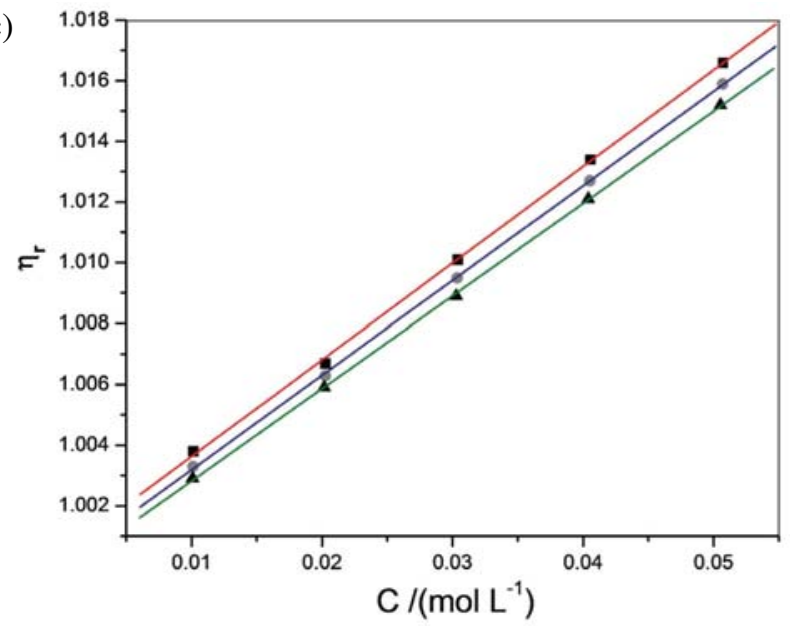

structural modification induced by solute-solvent interaction. ${ }^{35,36}$ For non-electrolytes, $\mathrm{A}$ is negligible ${ }^{35}$ and Jones-Dole equation reduces to:

$$
\eta_{\mathrm{r}}=\eta / \eta_{\mathrm{o}}=1+\mathrm{BC}
$$

b)

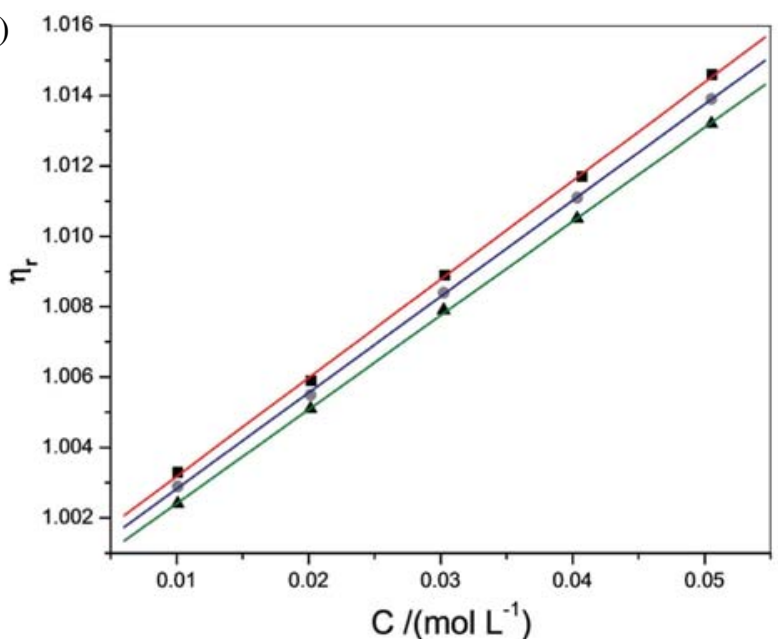

d)

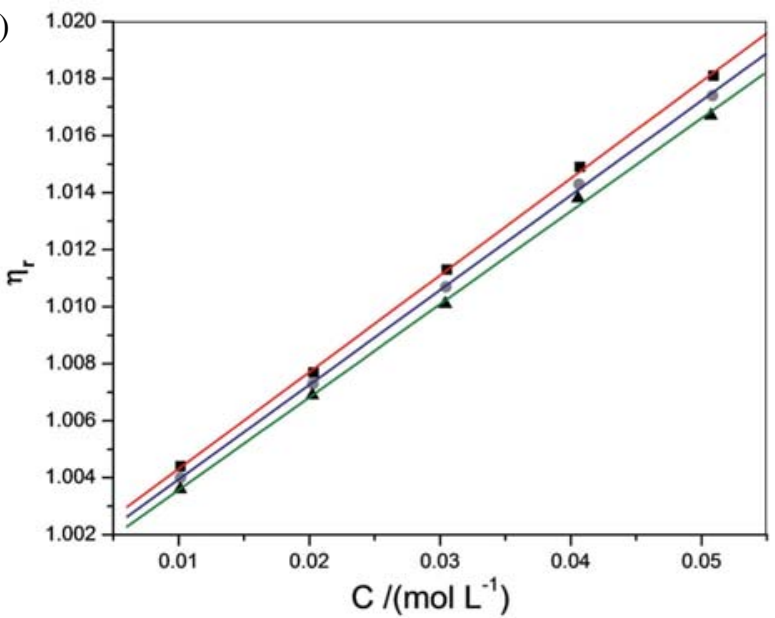

e)

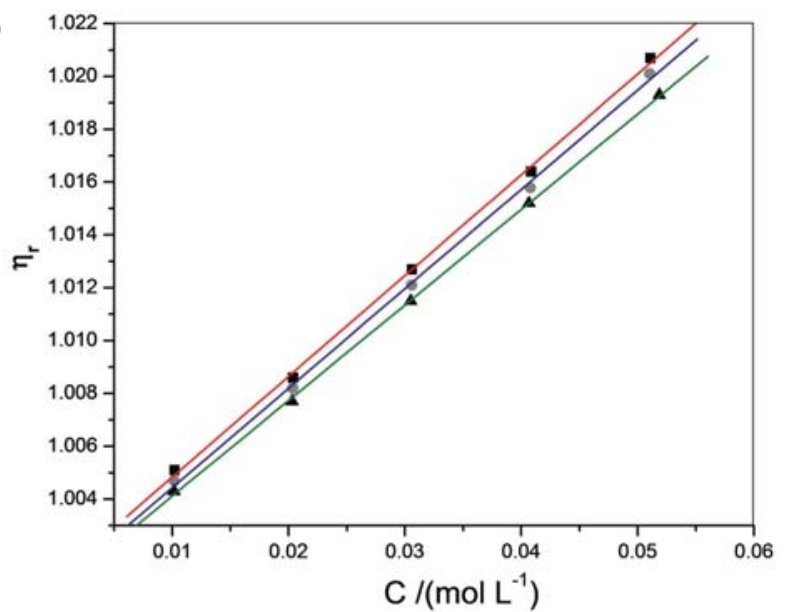

Figure 3. Variation of relative viscosity versus molarity of Asp in aqueous and aqueous + PD solutions: (a) water, (b) $5 \%$ PD, (c) $10 \%$ PD, (d) $15 \%$ PD and (e) 20\% PD at temperatures, T/K = $298.15(\boldsymbol{\square}) ; 303.15(\bullet) ; 308.15(\boldsymbol{\Delta})$. 
where $\mathrm{C}$ is the molarity obtained from molality by using our density values.

The values of B-coefficients, obtained using a plot between $\eta_{\mathrm{r}}$ and concentration (Table 8 ) by least squares analysis, are found to be linear at all concentrations and temperatures. The positive B-coefficients values, which increase with increasing concentration of $\mathrm{PD}$, also indicate a structure to allow the co-solute (PD) to act on solvent. ${ }^{4}$ The values of B-coefficients increase (i) when the water is replaced by PD, i.e., PD act as water structuremaker by H-bonding, and (ii) with increasing concentration of PD. The strong interaction immobilizes the solvent molecules, present obstruction to viscous flow of solution, thus, increasing the viscosity. ${ }^{37}$

The temperature derivative of B-coefficients $(\mathrm{dB} / \mathrm{dT})$ and its sign is useful in establishing structuremaking or structure-breaking ability of the solute in solvent. In general, the $\mathrm{dB} / \mathrm{dT}$ is negative for structure-maker and positive for structure-breaker solutes in solution. ${ }^{34,38}$ The $\mathrm{dB} / \mathrm{dT}$ values reported in Table 8 are negative which indicate that this amino acid, i.e., Asp act as structuremaker in aqueous-PD solvent.

\section{3. 1. Viscosity B-coefficients of Transfer}

The viscosity B-coefficients of transfer, $\mathrm{B}_{\mathrm{tr}}$, of Asp from aqueous to aqueous PD solutions was calculated using the following relation:

$$
\mathrm{B}_{\mathrm{tr}}=\mathrm{B}(\mathrm{aq}-\mathrm{PD} \text { solution })-\mathrm{B}(\mathrm{aq})
$$

where B (aq) is the viscosity B-coefficents of Asp in water (Table 8). The values of $B_{t r}$ are reported in Table 9 which shows that viscosity B-coefficients of transfer increase with increase in concentration of PD. Hence, the aforementioned transport parameters show similar trends based on the impact of hydrolysis reaction and dissociation constant of Asp as observed in the thermodynamic properties.

\section{4. Hydration Number}

The hydration number, $\mathrm{n}_{\mathrm{H}},{ }^{39-41}$ can be calculated from methods based on volume, compressibility and second temperature derivative of the partial molar volume or partial molar compressibility data. From volumetric properties (Table 10), the hydration number of an amino acid can be estimated from the electrostriction partial molar volume $\mathrm{V}_{\phi \text { (elect) }}^{0}$ by the following relation: ${ }^{23}$

$$
\mathrm{n}_{\mathrm{H}}=\mathrm{V}_{\phi(\text { elect })}^{0} /\left(\mathrm{V}_{\phi(\mathrm{e})}^{0}-\mathrm{V}_{\phi(\mathrm{b})}^{0}\right)
$$

where $\mathrm{V}_{\phi(\mathrm{e})}^{0}$ is the molar volume of electrostricted water and $\mathrm{V}_{\phi(b)}^{0}$ is the molar volume of the bulk. The values of $\left(\mathrm{V}_{\phi(\mathrm{e})}^{0}-\mathrm{V}_{\phi(\mathrm{b})}^{0}\right)$ are $(-3.3,-3.7$ and -4.0$) \mathrm{cm}^{3} \mathrm{~mol}^{-1}$ at $T=$ (298.15, 303.15, and 308.15) K. ${ }^{42}$ The electrostriction partial molar volume, $\mathrm{V}_{\phi(\mathrm{e})}^{0}$ can be estimated from the experimental measured $\mathrm{V}_{\phi}^{0}$ values by the following equation:

$$
\mathrm{V}_{\phi \text { (elect) }}^{0}=\mathrm{V}_{\phi \text { (amino acid) }}^{0}-\mathrm{V}_{\phi \text { (int) }}^{0}
$$

where $\mathrm{V}_{\phi \text { (int) }}^{0}$ is the intrinsic partial molar volume of the amino acid. The $\mathrm{V}_{\phi(\text { int })}^{0}$ is made up of two terms: the van der waals volume, $\mathrm{V}_{\phi(\mathrm{w})}^{0}$, and the volume due to packing effects, $\mathrm{V}_{\phi(\mathrm{P})}^{0}$, i.e.,

$$
\mathrm{V}_{\phi(\text { int })}^{0}=\mathrm{V}_{\phi(\mathrm{w})}^{0}+\mathrm{V}_{\phi(\mathrm{P})}^{0}
$$

The intrinsic volume can be calculated from several methods. One such approach is to estimate the intrinsic volume from crystal molar volume:

$$
\mathrm{V}_{\phi \text { (crystal) }}^{0}=\text { mol. wt. } / \mathrm{d}_{\text {crystal }}
$$

Table 8. Viscosity B-coefficients and temperature coefficients, dB/dT, of Asp in aqueous and aqueous solution of PD different temperatures.

\begin{tabular}{lcccc}
\hline System & Viscosity B-coefficients & & dB/dT \\
& $\mathbf{2 9 8 . 1 5 K}$ & $\mathbf{3 0 3 . 1 5 K}$ & $\mathbf{3 0 8 . 1 5 K}$ & \\
\hline Asp in aqueous & $0.248( \pm 0.005)$ & $0.240( \pm 0.003)$ & $0.233( \pm 0.001)$ & -0.0015 \\
Asp in 5\% aqueous PD & $0.280( \pm 0.003)$ & $0.273( \pm 0.002)$ & $0.267( \pm 0.001)$ & -0.0013 \\
Asp in 10\% aqueous PD & $0.318( \pm 0.004)$ & $0.311( \pm 0.002)$ & $0.304( \pm 0.002)$ & -0.0014 \\
Asp in 15\% aqueous PD & $0.340( \pm 0.004)$ & $0.332( \pm 0.004)$ & $0.326( \pm 0.006)$ & -0.0014 \\
Asp in 20\% aqueous PD & $0.381( \pm 0.007)$ & $0.376( \pm 0.007)$ & $0.361( \pm 0.003)$ & -0.0020 \\
\hline
\end{tabular}

Table 9. Viscosity B-coefficients of transfer, $B_{\text {tr }}$ of Asp in aqueous solution of PD at different temperatures.

\begin{tabular}{lccc}
\hline System & $\mathbf{2 9 8 . 1 5} \mathbf{~ K}$ & $\mathbf{3 0 3 . 1 5} \mathbf{~ K}$ & $\mathbf{3 0 8 . 1 5 ~ K}$ \\
\hline Asp in 5\% aqueous-PD & 0.032 & 0.033 & 0.034 \\
Asp in 10\% aqueous-PD & 0.070 & 0.071 & 0.071 \\
Asp in 15\% aqueous-PD & 0.092 & 0.092 & 0.093 \\
Asp in 20\% aqueous-PD & 0.133 & 0.136 & 0.128 \\
\hline
\end{tabular}


where $\mathrm{d}_{\text {crystal }}$ is the density of dry amino acid. The packing density for molecules in organic crystals is about 0.7 . The packing density for random packing spheres is 0.634. By making the appropriate corrections for packing densities $(\rho)$, the intrinsic partial molar volume of the amino acid can be calculated as:

$$
\mathrm{V}_{\phi \text { (int) }}^{0}=(0.7 / 0.634) \mathrm{V}_{\phi(\text { crystal })}^{0}
$$

The values of $\mathrm{V}_{\phi \text { (crystal) }}^{0}$ is determined from the work of Berlin and Pallansh ${ }^{43}$ and thus the value of $\mathrm{V}_{\phi \text { (elect) }}^{0}$ can be calculated.

The $\mathrm{n}_{\mathrm{H}}$ values (volumetric method) for Asp in aqueous-PD solutions, given in Table 10, shows that the hydration number of Asp in PD solution is less than that in water and decrease with increasing concentration of PD which again indicates that the increase in solutecosolute interactions reduces the electrostriction effect of amino acids. It also suggests that PD has a dehydration effect on the Asp, i.e., water molecules are replaced by PD molecules with increasing concentration of PD in solution.

From compressibility data, the number of water molecules hydrated to the amino acid was calculated by using the method given by Millero et al., ${ }^{23}$

$$
\mathrm{n}_{\mathrm{H}}=-\mathrm{K}_{\phi, \mathrm{s}(\mathrm{elect})}^{0} /\left(\mathrm{V}_{\phi(\mathrm{b})}^{0} \times \mathrm{K}_{\phi, \mathrm{s}, \mathrm{b}}^{0}\right)
$$

where $\mathrm{K}_{\phi, \mathrm{s}, \mathrm{b}}^{0}$ is compressibility of bulk water. Value of $\mathrm{V}^{0}$ (b) $\times \mathrm{K}^{0}{ }_{\phi, \mathrm{s}, \mathrm{b}}$ is $\approx 0.81 \times 10^{-5} \mathrm{~m}^{3} \mathrm{~mol}^{-1} \mathrm{GPa}^{-1}$ (or, $8.1 \times 10^{-15}$ $\left.\mathrm{m}^{3} \mathrm{~mol}^{-1} \mathrm{~Pa}^{-1}\right)$. The electrostriction partial molar compressibility, $\mathrm{V}_{\phi \text { (elect) }}^{0}$, can be calculated from experimentally measured values of $\mathrm{K}_{\phi, \mathrm{s} \text { (amino acid) }}^{0}$ using the following equation:

$$
\mathrm{K}_{\phi, \mathrm{s} \text { (elect) }}^{0}=\mathrm{K}_{\phi, \mathrm{s} \text { (amino acid) }}^{0}-\mathrm{K}_{\phi, \mathrm{s} \text { (int) }}^{0}
$$

where $\mathrm{K}_{\phi, \mathrm{s} \text { (int.) }}^{0}$ is $\mathrm{K}_{\phi, \mathrm{s} \text { (isomer) }}^{0}$ and its value for Asp is $3 \times$ $10^{-6} \mathrm{~m}^{3} \mathrm{~mol}^{-1} \mathrm{GPa}^{-1}$ (or, $\left.3 \times 10^{-15} \mathrm{~m}^{3} \mathrm{~mol}^{-1} \mathrm{~Pa}^{-1}\right){ }^{23}$ Since the value of $\mathrm{K}_{\phi, \mathrm{s}}^{0}$ (int.) is less than $5 \times 10^{-6} \mathrm{~m}^{3} \mathrm{~mol}^{-1} \mathrm{GPa}^{-1}$ (or, $5 \times 10^{-15} \mathrm{~m}^{3} \mathrm{~mol}^{-1} \mathrm{~Pa}^{-1}$ ) for ionic crystals and many organic solutes in water, we can assume $\mathrm{K}_{\phi, \mathrm{s}}^{0}$ (int.) $=0$. Therefore, Eq. (18) becomes

$$
\mathrm{K}_{\phi \text { 's (elect) }}^{0}=\mathrm{K}_{\phi, \mathrm{s} \text { (amino acid) }}^{0}
$$

The values of $n_{H}$ estimated from Eq. (17) (Table 10) show similar behavior as discussed in volume data.

It is pertinent to mention here that when Asp is dissolved in water there is a strong interaction between ions of Asp and water molecules. The small water molecules are surrounded by the ions of Asp which result in electrostriction of water molecules. In other words. there is collapse of structure of water molecules. On addition of $\mathrm{PD}$ to this solution, there is strong interaction between ions of Asp and PD solvent which results in decrease in electrostriction effect. Thus, large number of water molecules of solute is associated with solvent molecules which increase the interactions among the ions. The electrostricted water becomes more like bulk water which has an open structure. Thus, Asp acts as structure maker in presence of PD solvent. A similar conclusion is evident from the compressibility as well as viscosity data.

\section{Conclusion}

Density, speed of sound and viscosity of Asp in aqueous and aqueous PD solvent (5\%,10\%, 15\% and $20 \%$ of PD in water) measured at different temperature have been reported in this study. From the experimental data, various parameters like apparent molar volume, limiting apparent molar volume, the corresponding slope, partial molar volume of transfer; apparent molar isentropic compressibility, limiting apparent molar isentropic compressibility, its slope, partial molar compressibility of transfer; relative viscosity viscosity B-coefficients, temperature derivative of B-coefficients, viscosity B-coefficients of transfer, and hydration number have been calculated. The result indicates the existence of strong solute-solvent interactions i.e. ionic-hydrophilic and hydrophilic-hydrophilic interactions. The extent of interactions increases with an increase in the molar mass of Asp and an increase in the concentration of PD solution. The negative value of temperature derivative of B-coefficients $(\mathrm{dB} / \mathrm{dT})$ indicate that this amino acid, i.e., Asp act as structure-maker in aqueous-PD solvent. The hydration numbers $\mathrm{n}_{\mathrm{H}}$ of the amino acids under investigation decrease with temperature as well as with increasing concentration of PD and this shows that both of these factors

\begin{tabular}{|c|c|c|c|c|c|c|}
\hline \multirow{2}{*}{ System } & \multicolumn{3}{|c|}{ Volume data } & \multicolumn{3}{|c|}{ Compressibility data } \\
\hline & $298.15 \mathrm{~K}$ & $303.15 \mathrm{~K}$ & $308.15 \mathrm{~K}$ & 298.15 K & $303.15 \mathrm{~K}$ & $308.15 \mathrm{~K}$ \\
\hline Asp in aqueous & 5.40 & 4.86 & 4.30 & 3.24 & 3.17 & 3.09 \\
\hline Asp in $5 \%$ aqueous-PD & 5.21 & 4.66 & 4.09 & 2.90 & 2.83 & 2.75 \\
\hline Asp in $10 \%$ aqueous-PD & 5.06 & 4.51 & 3.95 & 2.60 & 2.48 & 2.42 \\
\hline Asp in $15 \%$ aqueous-PD & 4.85 & 4.36 & 3.84 & 2.30 & 2.16 & 2.07 \\
\hline Asp in $20 \%$ aqueous-PD & 4.73 & 4.25 & 3.73 & 1.93 & 1.80 & 1.73 \\
\hline
\end{tabular}
cause a dehydration effect on the amino acids.

Table 10. Hydration number, $\mathrm{n}_{\mathrm{H}}$, calculated from volume and compressibility data of Asp in aqueous and aqueous solution of PD at different temperatures. 


\section{Acknowledgements}

The authors are thankful to the Department of Chemistry, University of Jammu, Jammu for providing the necessary facilities for the completion of this work.

\section{References}

1. T. S. Banipal, J. Kaur, P. K. Banipal, K. Singh, J. Chem. Eng. Data. 2008, 53, 1803-1816. http://dx.doi.org/10.1021/je8001464

2. A. Pal, S. Kumar, J. Chem. Thermodyn. 2005, 37, 10851092. http://dx.doi.org/10.1016/j.jct.2004.12.015

3. A. K. Nain, D. Chand, J. Chem. Thermodyn. 2009, 41, 243249. http://dx.doi.org/10.1016/j.jct.2008.09.008

4. C. Zhao, P. Ma, J. Li, J. Chem. Thermodyn. 2005, 37, 37-42. http://dx.doi.org/10.1016/j.jct.2004.07.030

5. K. Zhuo, Q. Liu, Y. Wang, Q. Ren, J. Wang, J. Chem. Eng. Data. 2006, 51, 919-927. http://dx.doi.org/10.1021/je050412t

6. Z. Yan, J. Wang, W. Kong, J. Lu, Fluid. Phase. Equilib. 2004, 215,143-150. http://dx.doi.org/10.1016/j.fluid.2003.07.001

7. C. M. Romero, E. Moreno, J. L. Rojas, Thermochim. Acta. 1999, 328, 33-38. http://dx.doi.org/10.1016/S0040-6031(98)00621-2

8. A. K. Nain, M. Lather, R. K. Sharma, J. Mol. Liq. 2011, 159, 180-188. http://dx.doi.org/10.1016/j.molliq.2011.01.010

9. P. H. Yancey, M. E. Clark, S. C. Hand, R. D. Bowlus, G. N. Somero, Science. 1982, 217, 1214-1222. http://dx.doi.org/10.1126/science.7112124

10. P. H. Yancey, J. Exp. Biol. 2005, 208, 2819-2830. http://dx.doi.org/10.1242/jeb.01730

11. J. A. Schellman, J. Biophys. 2003, 85, 108-125. http://dx.doi.org/10.1016/S0006-3495(03)74459-2

12. T. V. Chalikian, Biophys. Chem. 2011, 156, 3-12. http://dx.doi.org/10.1016/j.bpc.2010.12.004

13. J. F. Back, D. Oakenfull, M. B. Smith, Biochem. 1979, 18, 5191-5196. http://dx.doi.org/10.1021/bi00590a025

14. Y. Fujita, Y. Iwasa, Y. Noda, Bull. Chem. Soc. Jpn. 1982, 55, 1896-1900. http://dx.doi.org/10.1246/bcsj.55.1896

15. M. Wusteman, S. Boylan, D. E. Pegg, Cryobiology. 199633 , 423-429. http://dx.doi.org/10.1006/cryo.1996.0042

16. D. P. Kharakoz, J. Phys. Chem. 1991, 95, 5634-5642. http://dx.doi.org/10.1021/j100167a049

17. M. Bastos, N. N. Volkova, I. Wadso, J. Chem. Soc. Faraday. Trans. 1993, 89, 1351-1352. http://dx.doi.org/10.1039/FT9938901351

18. D. G. Paola, B. Belleau, Can. J. Chem. 1978, 56, 1827-1831. http://dx.doi.org/10.1139/v78-296

19. T. S. Banipal, K. Singh, P. K. Banipal, J. Soln. Chem. 2007, $36,1635-1667$.
20. T. S. Banipal, K. Singh, P. K. Banipal, J. Kaur, J. Chem. Thermodyn. 2008, 40, 1166-1185. http://dx.doi.org/10.1016/j.jct.2008.02.007

21. R. S. Rani, A. C. Leela, G. N. Rao, Proc. Natl. Acad. Sci. 2012, 82, 313-316.

22. M. Singla, H. Kumar, R. Jindal, J. Chem. Thermodyn. 2014, 76, 100-115. http://dx.doi.org/10.1016/j.jct.2014.03.015

23. F. J. Millero, A. L. Surdo, C. Shin, J. Phys. Chem. 1978, 82, 784-792. http://dx.doi.org/10.1021/j100496a007

24. A. K. Mishra, J. C. Ahluwalia, J. Phys. Chem. 1984, 88, 86-92. http://dx.doi.org/10.1021/j150645a021

25. C. Liu, L. Zhou, R. Lin, J. Soln. Chem. 2007, 36, 923-937.

26. G. R. Hedwig, H. Hoiland, J. Chem. Thermodyn. 1993, 25, 349-354. http://dx.doi.org/10.1006/jcht.1993.1035

27. S. Banerjee, N. Kishore, J. Soln. Chem. 2005, 34,137-153.

28. H. Kumar, M. Singla, R. Jindal, Monatsh. Chem. 2014, 145, 1063-1082. http://dx.doi.org/10.1007/s00706-014-1183-z

29. H. S. Frank, M. W. Evans, J. Chem. Phys. 1945, 13, 507532. http://dx.doi.org/10.1063/1.1723985

30. A. W. Hakin, M. M. Duke, J. L. Marty, K. E. Preuss, J. Chem. Soc. Faraday Trans. 1994, 90, 2027-2035. http://dx.doi.org/10.1039/ft9949002027

31. C. Jolicoeur, B. Riedl, D. Desrochers, L. L. Lemelin, R. Zamojska, O. Enea, J. Soln. Chem. 1986, 15, 109-128.

32. G. Jones, M. Dole, J. Am. Chem. Soc. 1929, 51, 2950-2964. http://dx.doi.org/10.1021/ja01385a012

33. A. Chandra, V. Patidar, M. Singh, R. K. Kale, J. Chem. Thermodyn. 2013, 65, 18-28. http://dx.doi.org/10.1016/j.jct.2013.05.037

34. D. Feakins, D. J. Freemantle, K. G. Lawrence, J. Chem. Soc. Faraday. Trans. 1974, 70, 795-806 http://dx.doi.org/10.1039/f19747000795

35. R. L. Kay, T. Vituccio, C. Zawoyski, D. F. Evans, J. Phys. Chem. 1966, 70, 2336-2341. http://dx.doi.org/10.1021/j100879a041

36. H. D. B. Jenkins, Y. Marcus, Chem. Rev. 1995, 95, 26952724. http://dx.doi.org/10.1021/cr00040a004

37. A. K. Nain, R. Pal, Neetu, J. Chem. Thermodyn. 2013, 64, 172-181. http://dx.doi.org/10.1016/j.jct.2013.05.012

38. M. Kaminsky, Discuss. Faraday. Soc. 1957, 24, 171-179. http://dx.doi.org/10.1039/df9572400171

39. T. S. Banipal, G. Singh, Ind. J. Chem. 2004, 43A, 11561166.

40. T. S. Banipal, G. Singh, Thermochim. Acta. 2004, 412, 63-83. http://dx.doi.org/10.1016/j.tca.2003.08.026

41. T. V. Chalikian, A. P. Sarvazyan, K. J. Breslauer, J. Phys. Chem. 1993, 97, 13017-13026. http://dx.doi.org/10.1021/j100151a061

42. Z. Yan, X. Sun, W. W. Li, Y. Li, J. Wang, J. Chem. Thermodyn. 2011, 43, 1468-1474. http://dx.doi.org/10.1016/j.jct.2011.04.020

43. E. Berlin, M. J. Pallansch, J. Phys. Chem. 1968, 72, 18871889. http://dx.doi.org/10.1021/j100852a004 


\section{Povzetek}

Z meritvami gostote, viskoznosti in hitrosti zvoka v raztopinah smo proučevali interakcije L-asparaginske kisline (Asp) $\mathrm{v}$ mešanicah 1,2-propandiola (PD) in vode pri treh temperaturah $(298.15,303.15$ in 308.15) K pri atmosferskem tlaku. Iz eksperimentalnih podatkov za gostote raztopin smo določili navidezni molski volumen $\mathrm{V}_{\phi}$, vrednosti limitnega molskega volumna, $\mathrm{V}_{\phi}^{0}$, ter parcialni molski volumen prenosa, $\mathrm{V}_{\phi, t r}^{0}$. Iz izmerjenih vrednosti hitrosti zvoka smo izračunali navidezno molsko kompresibilnost, $\mathrm{K}_{\phi, \mathrm{tr}, \mathrm{s}}$ ter parcialno molsko kompresibilnost prenosa partial, $\mathrm{K}_{\phi, \mathrm{s}, \mathrm{tr}}^{0}, \mathrm{~S}$ pomočjo dobljenih vrednosti smo ocenili število vodnih molekul v hidratnem plašču amino kisline, $\mathrm{n}_{\mathrm{H}}$. Podatke za viskoznost smo uporabili pri izračunu relativne viskoznosti, $\eta_{\mathrm{r}}$, viskoznostnih B-koeficientov, njihovih odvodov po temperaturi, dB/dT, ter B-koeficientov prenosa, $B_{t r}$. Dobljene vrednosti smo uporabili za oceno prevladujočih interakcij $v$ proučevanih raztopinah. 